\title{
Tetra-Au(I) Complexes Bearing a Pyrene Tetraalkynyl Connector Behave as Fluorescence Torches
}

\author{
Ana Gutiérrez-Blanco, ${ }^{\dagger}$ Vanesa Fernández-Moreira, ${ }^{\ddagger} \oplus$ M. Concepción Gimeno, ${ }^{\ddagger}$ Eduardo Peris, ${ }^{\dagger \odot}$ \\ and Macarena Poyatos $*, \dagger$ \\ ${ }^{\dagger}$ Institute of Advanced Materials (INAM). Universitat Jaume I, Av. Vicente Sos Baynat s/n, E-12071 Castellón, Spain \\ "Departamento de Química Inorgánica, Instituto de Síntesis Química y Catálisis Homogénea (ISQCH), CSIC-Universidad de \\ Zaragoza, 50009 Zaragoza, Spain
}

Supporting Information

ABSTRACT: A pyrene tetraalkynyl ligand has been used for the preparation of three different tetraalkynyl $\mathrm{Au}(\mathrm{I})$ complexes. Two of these complexes display fluorescent emission in $\mathrm{CH}_{2} \mathrm{Cl}_{2}$ solution, with quantum yields exceeding $90 \%$. Although the emission is mainly due to ligand-centered excited states, the presence of the metal center is key to reaching such excellent quantum yield values, providing an extra rigidity to the system and therefore, minimizing the nonradiative deactivation pathways. To the best of our knowledge, these quantum yields lie among the highest reported for metal-based luminophores in solution, a quality that makes them resemble molecular torches. Preliminary studies on healthy cheek cells show that one of the complexes is efficiently and rapidly taken up into the cell.

\section{INTRODUCTION}

Since the discovery of luminescent organic devices, ${ }^{1}$ there has been increasing interest in the development of materials with emissive properties, mostly due to their applications as fluorescent sensors, ${ }^{2}$ light-emitting diodes (OLEDs), ${ }^{3}$ and bioimaging probes. ${ }^{4}$ Although luminescent materials may find applications in every physical state, the vast majority are used as films and aggregates, as for example in the fabrication of OLEDs. This justifies why much effort has been directed to the study of the aggregation-induced emission (AIE) phenomenon, a process for which nonemissive luminogens are induced to emit by aggregate formation. ${ }^{5}$ However, in the area of biomedical research, luminophores are often used in solution; therefore, it is very important to find new materials that show good emission properties in dilute solutions. If the luminophores are also able to show chemotherapeutic activity, then optical theranostic agents may be obtained, which could provide relevant information about their biological interplay. ${ }^{6}$ Luminescent transition-metal compounds have attracted intense attention during the last two decades. ${ }^{7}$ One of the main reasons for the great success of metal-based chromophores is that the heavy atom enhances spin-orbit coupling to yield partial mixing between triplet and singlet excited states, allowing a fast rate of intersystem crossing followed by phosphorescence and, sometimes, high quantum yields. Among transition-metal-based luminophores, gold(I) alkynyls constitute one of the most widely studied groups, probably because acetylides can connect the gold atom to a very large variety of organic functions. ${ }^{8}$ N-heterocyclic carbene (NHC) ligands have also been extensively used in the preparation of metal complexes with photoluminescent properties, because their strong $\sigma$-donating character ensures high-energy emissions that facilitate the desired blue color needed for OLED applications. ${ }^{9}$ While highly efficient emissions $(\phi>85 \%)$ have been found for a (low) number of gold complexes in the solid or aggregated states, ${ }^{10}$ to the best of our knowledge there is only one report describing comparably high quantum yields in solution. ${ }^{11}$ In most cases, the nature of the ligands, the oxidation state, the coordination geometry of the $\mathrm{Au}$ complexes, or the presence of metallic interactions determines the nature of the luminescence. Both fluorescence and phosphorescence have been achieved in gold(I) compounds, depending upon the participation of the metal in the excited states. It has been observed that, in complexes bearing organic fluorophores, there is in many cases a negligible participation of the metal atom in the excited states. This is usually translated in a decrease of the luminescent quantum yields in comparison to the fluorophore because of deactivation processes. In some cases, the $\mathrm{Au}(\mathrm{I})$ atom can have important structural implications in the enhancement of the emission, as in a recent article published by Strassert and Hahn describing an example of emission enhancement by rigidification through metal complexation. ${ }^{12}$

Herein, we describe three pyrene-based tetraalkynyl $\mathrm{Au}(\mathrm{I})$ complexes bearing aromatic NHC or phosphine ligands. Two of these complexes were found to be highly emissive in solution, a property mostly related to the central pyrene core

Received: April 12, 2018 
yet enhanced by the coordination of the metal fragments and consequent rigidification of the final system.

\section{RESULTS AND DISCUSSION}

We decided to prepare a series of tetra- $\mathrm{Au}(\mathrm{I})$ complexes connected by a pyrene tetraalkynyl ligand. Our initial aim was to combine pyrene-one of the most widely studied organic materials in the field of photochemistry and photophysics ${ }^{13}$ with gold(I) alkynyl compounds bearing NHC ancillary ligands and study their photophysical properties. As will be described below, this combination of components allowed us to obtain two of the most efficient Au-based fluorescence emitters in solution reported to date.

The pyrene-connected $\mathrm{Au}(\mathrm{I})$ complexes were synthesized according to the procedure depicted in Scheme 1. Complexes 3

\section{Scheme 1. Preparation of Complexes 3-5}

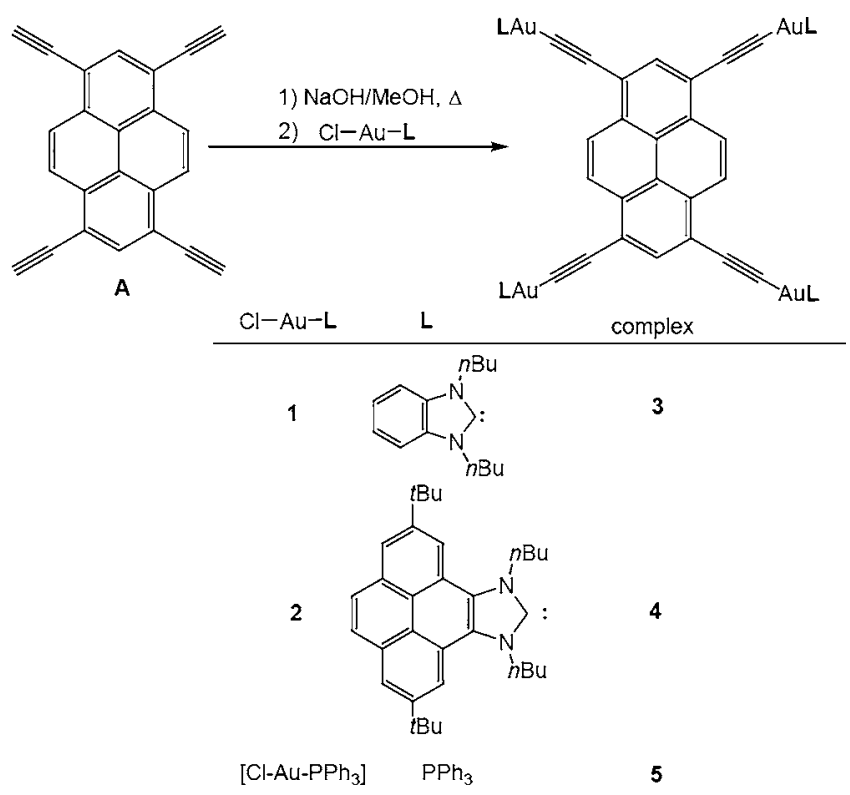

and 4 were prepared by deprotonating 1,3,6,8-tetraethynylpyrene (A) with $\mathrm{NaOH}$ in refluxing methanol, followed by the addition of benzimidazolylidene gold(I) complex $1^{14}$ or pyrene imidazolylidene gold(I) complex $2,{ }^{15}$ respectively. Following the same synthetic protocol, the triphenylphosphine-based $\mathrm{Au}(\mathrm{I})$ complex 5 was prepared by reacting $\mathbf{A}$ with $[\mathrm{AuCl}-$ $\left.\left(\mathrm{PPh}_{3}\right)\right]$ in the presence of $\mathrm{NaOH}$. Complexes 3-5 were isolated in yields ranging from 40 to $60 \%$. All three complexes are highly soluble in chlorinated solvents, such as dichloromethane and chloroform, displaying very bright yellow solutions. Complexes 3-5 were characterized by NMR spectroscopy and gave satisfactory elemental analysis.

For complexes 3 and $\mathbf{4}$, the number and integration of the signals displayed in the ${ }^{1} \mathrm{H}$ NMR spectra are in agreement with the presence of four NHC ligands with respect to the pyrene core. The ${ }^{13} \mathrm{C}$ NMR spectra of 3 and 4 revealed the appearance of signals due to the four equivalent metalated carbene carbons at 194.90 and $193.52 \mathrm{ppm}$, respectively.

The molecular structure of complex 3 was confirmed by means of X-ray diffraction. As depicted in Figure 1, the molecule consists of four benzimidazolylidene-Au(I) units connected by a pyrene tetraacetylide ligand. Two of the benzimidazolylidene ligands form an angle of $68.38^{\circ}$ with respect to the plane of the pyrene linker, while the two

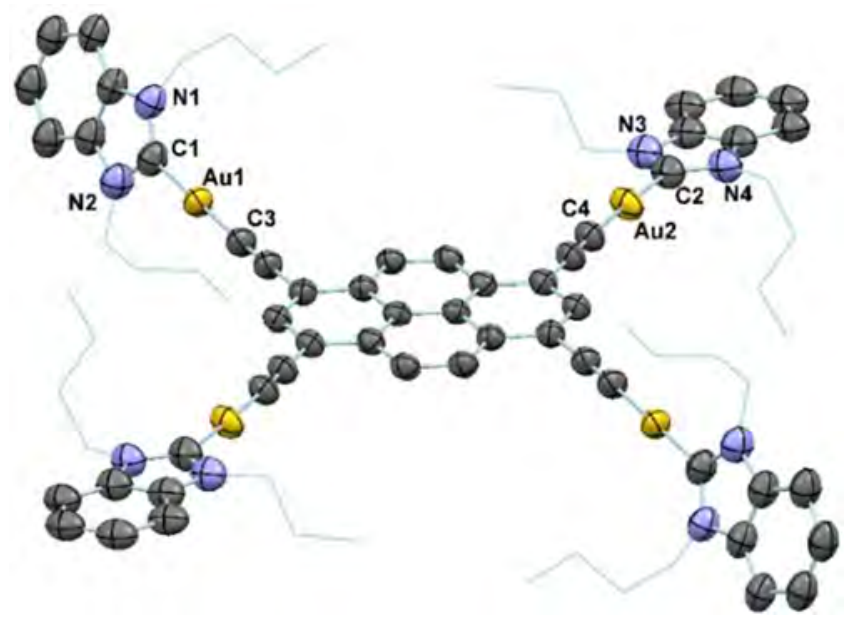

Figure 1. Molecular structure of 3. Hydrogen atoms are removed for clarity. $n \mathrm{Bu}$ groups are represented in wireframe form. Selected distances $(\AA)$ and angles (deg): $\mathrm{Au}(1)-\mathrm{C}(1) 2.027(12), \mathrm{Au}(1)-\mathrm{C}(3)$ 1.992(11), $\mathrm{Au}(2)-\mathrm{C}(2)$ 2.029(12), $\mathrm{Au}(2)-\mathrm{C}(4) 2.015(11) ; \mathrm{C}(2)-$ $\mathrm{Au}(2)-\mathrm{C}(4) 176.9(5), \mathrm{C}(3)-\mathrm{Au}(1)-\mathrm{C}(1) 177.2(5)$.

remaining ligands are quasi-coplanar with the pyrene linker, as reflected by the small angle formed by the planes of the pyrene and the NHC fragments, $7.06^{\circ}$. The $\mathrm{Au}-\mathrm{C}_{\text {carbene }}$ bond distances are 2.017-2.029 A. All other distances and angles are unexceptional. The crystal packing of the molecules shows that there is a two-dimensional array produced by the $\pi$ stacking interactions between the pyrene core and the benzene rings of opposite benzimidazolylidene ligands (see Figure S7 of the Supporting Information). The distance between planes is $3.45 \AA$, which is indicative of a $\pi$-stacking interaction. The $\mathrm{Au}-$ $\mathrm{Au}$ distance is $4.38 \AA$ and therefore greater than the distances that can be considered within the range of aurophilic interactions $(2.8-3.5 \AA){ }^{16}$

The UV-visible absorption and the emission spectra of complexes 3 and 4 were studied in dichloromethane at $298 \mathrm{~K}$ (Table 1). The UV-vis spectrum of compound A displays one vibronically resolved band in the region of $350-450 \mathrm{~nm}$, assigned to pyrene-centered transitions. The acetylene-centered $\pi-\pi^{*}$ transitions are observed as intense absorptions between 270 and $320 \mathrm{~nm}$. The UV-vis spectra of complexes 3 and 4 show two intraligand transitions centered at the pyrene and acetylide units, although they are significantly red shifted in comparison to those of compound $\mathbf{A}$, as a consequence of the perturbation produced by the coordination to the metal (see Figure S9 of the Supporting Information).

The emission spectra of complexes 3 and 4 in $\mathrm{CH}_{2} \mathrm{Cl}_{2}$ show a pyrene-centered vibronically resolved band, which is bathochromically shifted $(\Delta \lambda \approx+75 \mathrm{~nm})$ in comparison to the emission shown by A (Figure 2). Possibly, coordination of the gold atom to the alkynyl moiety withdraws the electron density of the latter and in consequence there is an stabilization of the LUMO orbital. Interestingly, the lowest energy emission bands of the $\mathrm{Au}(\mathrm{I})$ complexes occurred at $546 \mathrm{~nm}$, well into the visible region, thus justifying their bright visible emission. The excited-state lifetimes of $\mathbf{A}$, as well as of complexes $\mathbf{3}$ and $\mathbf{4}$, were found to be monoexponential and to be on the order of nanoseconds, therefore indicating the fluorescence nature of the emission and the apparent lack of participation of the metal in the electronic excited states. This observation is in accordance with the results found by Che and co-workers for 
Table 1. Photophysical Data for $\mathrm{A}$ and $3-5$ in $\mathrm{CH}_{2} \mathrm{Cl}_{2}$ Solution ${ }^{a}$

\begin{tabular}{llcllll} 
& \multicolumn{1}{c}{$\lambda_{\text {abs }}(\mathrm{nm})$} & $\lambda_{\mathrm{em}}{ }^{a}(\mathrm{~nm})$ & $\tau^{b}(\mathrm{~ns})$ & $\phi_{\mathrm{em}}{ }^{c}$ & $K_{\mathrm{r}}\left(10^{8} \mathrm{~s}^{-1}\right)$ & \multicolumn{1}{c}{$K_{\mathrm{nr}}\left(10^{8} \mathrm{~s}^{-1}\right)$} \\
$\mathbf{A}$ & $416,391,371,306,294,255,246$ & $473(\mathrm{sh}), 445,422$ & 4 & 0.58 & 1.45 & 1.08 \\
$\mathbf{3}$ & $471,441,415,342,290,282,238$ & $543(\mathrm{sh}), 507,481$ & 2 & 0.90 & 4.5 & 0.5 \\
$\mathbf{4}$ & $472,442,416,342,282,253$ & $546(\mathrm{sh}), 508,481$ & 1 & 0.38 & 3.8 & 6.8 \\
$\mathbf{5}$ & $469,441,413,336,268,228$ & $540(\mathrm{sh}), 505,476$ & 3 & 0.92 & 3.06
\end{tabular}

${ }^{a}$ Measurements performed in $\mathrm{CH}_{2} \mathrm{Cl}_{2}$ solution under ambient conditions $\left(\lambda_{\text {exc }} 345 \mathrm{~nm}\right) .{ }^{b}$ Excited state lifetime measured in degassed $\mathrm{CH}_{2} \mathrm{Cl}_{2}$ solution $\left(\lambda_{\text {exc }} 345 \mathrm{~nm}\right.$ with prompt use). ${ }^{c}$ Quantum yields measured in degassed $\mathrm{CH}_{2} \mathrm{Cl}_{2}$ solution with excitation at $370 \mathrm{~nm}$ (absolute method). Deactivation rate constants were calculated by $K_{\mathrm{r}}=\phi_{\mathrm{em}} / \tau$ and $K_{\mathrm{nr}}=\left((1 / \tau)-K_{\mathrm{r}}\right){ }^{17}$

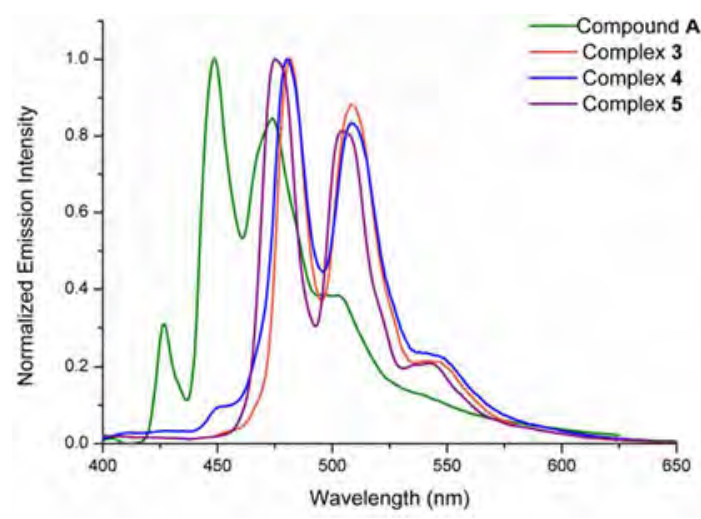

Figure 2. Fluorescence emission spectra of compound $\mathbf{A}$ and complexes 3-5 in dichloromethane, upon excitation at $345 \mathrm{~nm}$.

their highly emissive $\mathrm{Au}(\mathrm{I})$ alkynyl complexes, where very small lifetimes were found, and the emissions are attributable to ligand-centered transitions with a small contribution of MLCT. $^{11}$

Complexes 3 and 4 were found to be remarkably emissive in solution, with fluorescence quantum yields of 0.90 and 0.38 , respectively. As previously reported for species $\mathbf{A}$, the presence of molecular oxygen barely affects the quantum yield values of 3-5 as consequence of the short excited-state lifetimes. ${ }^{17}$ It is worth mentioning that complex 3 has a photoluminescence quantum yield considerably higher than that found for $\mathbf{A}\left(\phi_{\mathrm{em}}\right.$ $=0.58$ ).

This makes complex 3 among the most emissive gold NHC complexes reported to date in solution. It is also worth mentioning that there is a notable difference between the emission intensity exhibited by complexes $\mathbf{3}$ and $\mathbf{4}$ and that of the monometallic $\mathrm{Au}(\mathrm{I}) \mathrm{NHC}$ complexes 1 and 2, which were found to be nonemissive under the same conditions. In order to assess if the NHC ligand played a role in the emissive properties of complexes 3 and 4, we also measured the photophysical properties of the phosphine-containing complex $\mathbf{5}$, for which an extraordinary high quantum yield of 0.92 was observed (Table 1). This result indicates that both NHC ligands might play a different role in the luminescence efficiency. Whereas in the case of complex 3 a negligible participation of the NHC is observed, the pyrene imidazolylidene NHC derivative in complex 4 might promote an additional nonradiative deactivation pathway because of its extended $\pi$ conjugation and higher electron-donating character. ${ }^{18}$ Radiative $\left(K_{\mathrm{r}}\right)$ and nonradiative $\left(K_{\mathrm{rn}}\right)$ rate constants were calculated to assess the existence of an additional nonradiative deactivation pathway for complex 4 (see Table 1). In all cases, both rate constants were on the order of $10^{8}$, a much higher value than that of the pyrene itself $\left(10^{6} \mathrm{~s}^{-1}\right),{ }^{19}$ which is in accordance with their small excited-state lifetime value (1-4 ns). ${ }^{17}$ In general, it was observed that the radiative rate constant value was higher than the nonradioactive rate constant except for complex 4, corroborating the extra deactivation pathway for this complex and consequently leading to a smaller quantum yield value. In any case, it seems clear that the gold metal center gives the alkynyl pyrene platform extra rigidity that highly increases the emission efficiency. As an illustrative image of the extraordinary emission properties of these complexes, Figure 3 shows a photograph of solutions of $\mathbf{A}$ and $\mathbf{3 - 5}$ in $\mathrm{CH}_{2} \mathrm{Cl}_{2}$ and in the solid state, upon irradiation with UV light $\left(\lambda_{\mathrm{ex}} 365 \mathrm{~nm}\right)$.

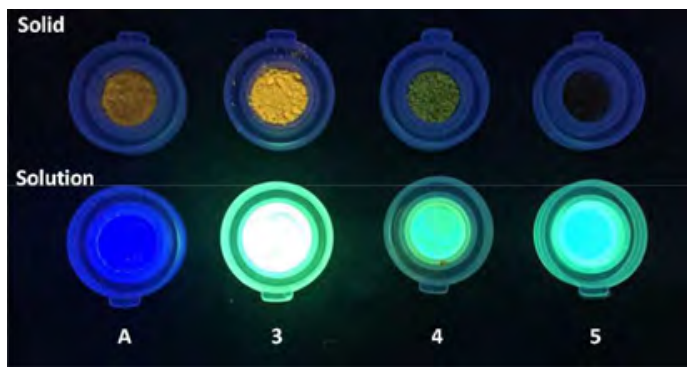

Figure 3. Photograph of $\mathbf{A}$ and $\mathbf{3 - 5}$ in the solid state (top) and in $\mathrm{CH}_{2} \mathrm{Cl}_{2}$ solution (bottom), under UV light at $365 \mathrm{~nm}$.

The emission spectra of complexes $\mathbf{3 - 5}$ in the solid state at room temperature reveal one broad and featureless band typical of the pyrene excimer emission, with maxima at 585, 541, and $650 \mathrm{~nm}$, respectively. The excited lifetimes of these bands are on the order of nanoseconds, and the quantum yields are $2.2 \%$ for 3 and $<1 \%$ for $\mathbf{4}$ and $\mathbf{5}$. We attribute the bathochromic shift of the solid-state emission spectra in comparison to those of the solutions to intermolecular $\pi-\pi$ interactions occurring in the solid state, as demonstrated in the X-ray molecular structure of 3. These $\pi-\pi$ stacking interactions should also justify the quenching of the emission produced by aggregation-caused quenching (ACQ). The low excited-state lifetimes are in accordance with the fluorescent nature of the emission of the solids, therefore discarding the presence of $\mathrm{Au} \cdots \mathrm{Au}$ interactions in the solid state, which would very likely produce delayed fluorescence or phosphorescence. We were also interested in studying the self-assembly capabilities of complexes $\mathbf{3}$ and $\mathbf{4}$ in solution. For this purpose, we obtained a series of ${ }^{1} \mathrm{H}$ NMR spectra of the two complexes at different concentrations, using $\mathrm{CDCl}_{3}$. The representative concentration-dependent ${ }^{1} \mathrm{H} \mathrm{NMR}$ spectra at room temperature and labeling of the protons for complex 3 are given in Figure S15 of the Supporting Information.

The analysis of the signals of the spectra indicates that two signals assigned to the aromatic protons of the pyrene scaffold and two signals due to the aromatic protons of the benzimidazolylidene ligands are shifted downfield upon decreasing the concentration of the complex. This behavior is 
strongly suggestive of the presence of aggregation driven by intermolecular $\pi-\pi$ stacking interactions between these two parts of the molecule, as is also observed in the crystal packing of the molecule. No significant changes were detected in the ${ }^{1} \mathrm{H}$ NMR spectra of 4 in $\mathrm{CDCl}_{3}$ in the range of concentrations studied $(0.1-20 \mathrm{mM})$. A nonlinear regression analysis of the data of this series of spectra allowed us to calculate a selfassociation constant of $48 \mathrm{M}^{-1}$, thus demonstrating the propensity of 3 to form $\pi$-stacking aggregates.

This self-aggregation is responsible for some interesting photophysical consequences, as self-aggregation is temperaturedependent.

As can be observed in Figure 4, the color of the emission of a $\mathrm{CH}_{2} \mathrm{Cl}_{2}$ solution of 3 can switch from blue to yellow, by

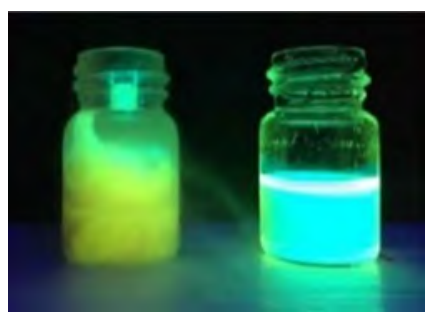

Figure 4. Photograph showing a solution of 3 in $\mathrm{CH}_{2} \mathrm{Cl}_{2}$ at $77 \mathrm{~K}$ (frozen solution, left) and at room temperature (right), under UV light at $365 \mathrm{~nm}$.

freezing the solution at $77 \mathrm{~K}$. It could be suggested that lowering the temperature might prompt the formation of aggregates of 3 , which behave similarly to the solid state.

In view of the supramolecular self-assembly capability of complex 3, the morphology of the aggregates was studied by scanning electron microscopy (SEM). For comparative purposes, SEM images of a sample of complex 4 were also recorded. SEM images of 3, prepared by slow diffusion of $\mathrm{MeOH}$ into a saturated solution of the complex in chloroform, show needles with a laminar nanostructure. On the other hand, SEM images of a sample of 4, prepared by slow diffusion of hexane into a saturated solution of the complex in dichloromethane, show a disordered fiberlike nanostructure (Figure 5).

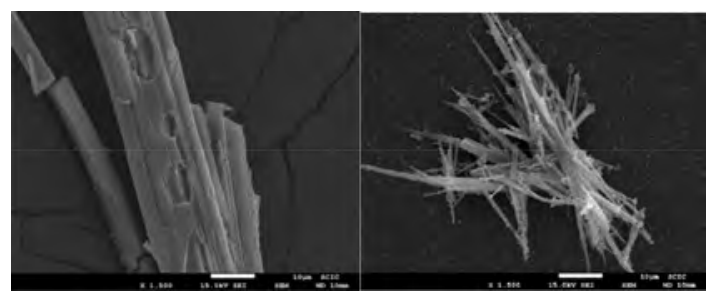

Figure 5. SEM micrographs of 3 (left) and 4 (right) at a magnification value of $1500 \times$.

The combination of the fluorescence properties of complexes $3-5$ with the well-stablished therapeutic properties of $\mathrm{Au}(\mathrm{I})^{20}$ makes these complexes potential candidates as optical theranostic agents. ${ }^{6}$ Regardless of their application as diagnostic and/or therapeutic agents, establishing their rapid and efficient cellular uptake is of crucial importance. Given the high quantum yield and stability of 3 , we selected it to monitor its uptake into healthy cheek cells (more details can be found in the Supporting Information). The actual transport of 3 into the cellular interior, rather than association solely at the membrane surface, is evident by confocal microscopy upon excitation at $405 \mathrm{~nm}$. The colors shown in the confocal microscopy figures is arbitrary. Purple was chosen here to enhance visualization of the emissive zones of the cell. Intense luminescence in the cytoplasm is apparent within 15 min (Figure 6, left).
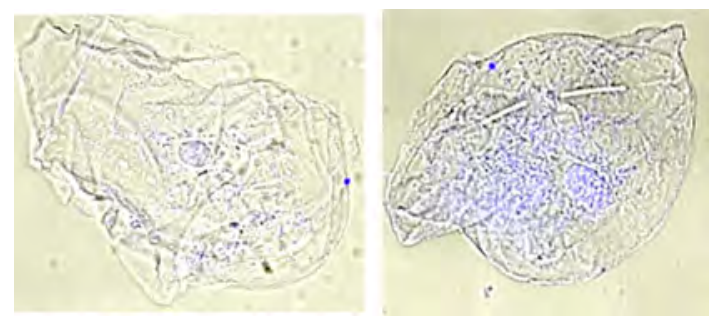

Figure 6. Confocal microscopy of healthy cheek cells treated with complex 3 for $15 \mathrm{~min}$ (left) and $30 \mathrm{~min}$ (right), excited at $405 \mathrm{~nm}$.

After $30 \mathrm{~min}$, intense luminescence can be also observed in the nucleus (Figure 6, right), thus proving that the uptake of 3 into the cell interior is efficient and rather rapid.

\section{CONCLUSIONS}

In summary, we obtained a series of pyrene tetraalkynyl complexes of $\mathrm{Au}(\mathrm{I})$ and studied their photophysical properties. Two of these complexes are among the most emissive $\mathrm{Au}(\mathrm{I})$ complexes described to date in solution. Although the origin of the emissions is assigned to an intraligand transition, coordination to the gold centers plays a key role, as it allows a red-shifted displacement of the emissions and an incredible enhancement of the quantum yields. We believe that the excellent emissive properties of these complexes in solution may find applications as bioimaging probes. Indeed, our preliminary studies on healthy cheek cells show that complex 3 is efficiently and rapidly taken up into the cell. Further studies involving cancer cells are currently underway.

\section{EXPERIMENTAL SECTION}

General Methods. 2,7-Di-tert-butylpyrene ${ }^{21}$ and 1,3,6,8-tetraethynylpyrene $(\mathbf{A})^{22}$ were prepared according to literature methods. NHCbased $\mathrm{Au}(\mathrm{I})$ complexes $\mathbf{1}^{14}$ and $\mathbf{2}^{15}$ were prepared as previously reported, starting from the corresponding benzimidazolium ${ }^{14}$ and pyrene imidazolium ${ }^{23}$ iodide salts, respectively. $\left[\mathrm{AuCl}\left(\mathrm{PPh}_{3}\right)\right]$ was prepared according to the literature. ${ }^{24}$ Anhydrous solvents were dried using a solvent purification system (SPS MBraun) or purchased and degassed prior to use by purging them with dry nitrogen. All of the reagents and solvents were used as received from commercial suppliers. NMR spectra were recorded on a Varian Innova 500 $\mathrm{MHz}$ or a Bruker $400 / 300 \mathrm{MHz}$ instrument, using $\mathrm{CDCl}_{3}$ as solvent. Elemental analyses were carried out on a TruSpec Micro Series apparatus. Infrared spectra (FTIR) were obtained with a FT/IR-6200 (Jasco) spectrometer with a spectral window of $4000-600 \mathrm{~cm}^{-1}$. UVvis absorption spectra were recorded on a Varian Cary $300 \mathrm{BIO}$ spectrophotometer in $\mathrm{CH}_{2} \mathrm{Cl}_{2}$ solution under ambient conditions. Room-temperature steady-state emission and excitation spectra were recorded with a Horiba Jobin Yvon Fluorolog FL3-11 spectrometer fitted with a JY TBX picosecond detection module. Lifetime measurements were recorded with an LED from Horiba Jobin Ybon with a pulse duration of 1.2 ns. LED frequencies were selected attending to excitation energies. A prompt was performed using LUDOX AS-40 colloidal silica, as a 40 wt \% suspension in water. Lifetime data were fitted using DAS6 V6.1 software. The quantum yields in solution were measured with an Absolute PL C11437 quantum yield spectrometer (Hamamatsu Photonics KK). The solvent was deaerated by sparging with nitrogen for $15 \mathrm{~min}$ prior to 
performing emission and quantum yield measurements. Scanning electron micrographs were taken with a JEOL Model 7001F field emission gun scanning electron microscope (FEG-SEM), equipped with an energy dispersion X-ray spectrometer (EDS) from Oxford Instruments. Confocal microscopy was performed on a Leica TCS SP8 inverted microscope using a $20 \times$ dry objective. The confocal microscope was equipped with a $405 \mathrm{~nm}$ diode.

Healthy cheek cells were collected by buccal smear using a sterile interdental brush. The brush was immediately immersed in a small vial containing $10 \mathrm{~mL}$ of saline solution. A few drops of a solution of the metal complex in DMSO were added to the saline solution. Confocal microscopy images were taken after approximately $15 \mathrm{~min}$. For comparative purposes, confocal microscopy images of nontreated cells were also taken, but no fluorescence was observed under the same measurement conditions.

Synthesis of the $\mathrm{Au}(\mathrm{I})$ Complexes. General Procedure. $\mathrm{NaOH}$ (7 equiv) and 1,3,6,8-tetraethynylpyrene (1 equiv) were placed together in a Schlenk tube. The tube was evacuated and filled with nitrogen three times. The solids were suspended in degassed $\mathrm{MeOH}$, and the resulting solution was heated under reflux for $4 \mathrm{~h}$. Then, the reaction mixture was allowed to reach room temperature and the corresponding NHC-based $\mathrm{Au}(\mathrm{I})$ complex ( 1 or $2,4.2$ equiv) was added. The resulting suspension was heated at reflux overnight. The resulting bright suspension was allowed to reach room temperature. After removal of the volatiles, the crude solid was suspended in dichloromethane and filtered through a pad of Celite. The solvent was removed under vacuum. Whereas complexes $\mathbf{3}$ and $\mathbf{4}$ were found to be stable in the solid state as well as in solution, complex $\mathbf{5}$ suffered decomposition in solution within hours, which prevented recording a suitable ${ }^{13} \mathrm{C}$ NMR spectrum.

Synthesis of 3. Complex 1 ( $200 \mathrm{mg}, 0.433 \mathrm{mmol})$ was added to a suspension of compound A (31 mg, $0.104 \mathrm{mmol})$ and $\mathrm{NaOH}(30 \mathrm{mg}$, $0.728 \mathrm{mmol})$ in $\mathrm{MeOH}(40 \mathrm{~mL})$. After the general workup, the resulting solid was washed with $\mathrm{MeCN}$ and collected by filtration. Complex 3 was isolated as a bright yellow solid. Yield: $108.4 \mathrm{mg}$ (52\%). IR (KBr): $\nu 2102.03 \mathrm{~cm}^{-1}(\mathrm{C} \equiv \mathrm{C}) .{ }^{1} \mathrm{H}$ NMR $(300 \mathrm{MHz}$, $\left.\mathrm{CDCl}_{3}\right): \delta 8.82\left(\mathrm{~s}, 4 \mathrm{H}, \mathrm{CH}_{\mathrm{pyr}}\right), 8.38\left(\mathrm{~s}, 2 \mathrm{H}, \mathrm{CH}_{\mathrm{pyr}}\right), 7.43-7.41(\mathrm{~m}, 8 \mathrm{H}$, $\left.\mathrm{CH}_{\text {benz }}\right), 7.34-7.32\left(\mathrm{~m}, 8 \mathrm{H}, \mathrm{CH}_{\text {benz }}\right), 4.60\left(\mathrm{t},{ }^{3} \mathrm{~J}_{\mathrm{H}-\mathrm{H}}=14.6 \mathrm{~Hz}, 16 \mathrm{H}\right.$, $\mathrm{NCH}_{2} \mathrm{CH}_{2} \mathrm{CH}_{2} \mathrm{CH}_{3}$ ), 1.99 (q, $16 \mathrm{H}, \mathrm{NCH}_{2} \mathrm{CH}_{2} \mathrm{CH}_{2} \mathrm{CH}_{3}$ ), $1.53-1.46$ $\left(\mathrm{m}, 16 \mathrm{H}, \mathrm{NCH}_{2} \mathrm{CH}_{2} \mathrm{CH}_{2} \mathrm{CH}_{3}\right), 1.02\left(\mathrm{t},{ }^{3} \mathrm{~J}_{\mathrm{H}-\mathrm{H}}=14.7 \mathrm{~Hz}, 24 \mathrm{H}\right.$, $\left.\mathrm{NCH}_{2} \mathrm{CH}_{2} \mathrm{CH}_{2} \mathrm{CH}_{3}\right) .{ }^{13} \mathrm{C}\left\{{ }^{1} \mathrm{H}\right\}$ NMR $\left(75 \mathrm{MHz}, \mathrm{CDCl}_{3}\right): \delta 194.70$ $\left(\right.$ Au- $\left.C_{\text {carbene }}\right), 135.41\left(\mathrm{CH}_{\text {pyr }}\right), 135.12\left(C_{\text {q,pyr }}\right), 133.68\left(C_{\text {q,benz }}\right), 131.92$ $\left(C_{\mathrm{q} p \text { pyr }}\right), 126.78\left(\mathrm{CH}_{\mathrm{pyr}}\right), 124.56\left(\mathrm{C}_{\mathrm{q}, \mathrm{pyr}}\right), 124.03\left(\mathrm{CH}_{\mathrm{benz}}\right), 120.40$ $\left(C_{\mathrm{q}, \text { acetylide }}\right), 111.53\left(\mathrm{CH}_{\mathrm{benz}}\right), 104.59\left(\mathrm{C}_{\mathrm{q} \text {, acetylide }}\right), 48.78$ $\left(\mathrm{NCH}_{2} \mathrm{CH}_{2} \mathrm{CH}_{2} \mathrm{CH}_{3}\right), \quad 32.55\left(\mathrm{NCH}_{2} \mathrm{CH}_{2} \mathrm{CH}_{2} \mathrm{CH}_{3}\right), \quad 20.50$ $\left(\mathrm{NCH}_{2} \mathrm{CH}_{2} \mathrm{CH}_{2} \mathrm{CH}_{3}\right), 14.21\left(\mathrm{NCH}_{2} \mathrm{CH}_{2} \mathrm{CH}_{2} \mathrm{CH}_{3}\right)$. Anal. Calcd for $\mathrm{C}_{84} \mathrm{H}_{94} \mathrm{~N}_{8} \mathrm{Au}_{4}$ : C, 50.36; H, 4.73; N, 5.59. Found: C, 50.47; H, 5.03; N, 5.67.

Synthesis of 4. Complex $2(190 \mathrm{mg}, 0.272 \mathrm{mmol})$ was added to a suspension of compound $\mathbf{A}(19.4 \mathrm{mg}, 0.065 \mathrm{mmol})$ and $\mathrm{NaOH}(18$ $\mathrm{mg}, 0.455 \mathrm{mmol})$ in $\mathrm{MeOH}(40 \mathrm{~mL})$. Complex 4 was isolated as an orange solid after precipitation from a dichloromethane/diethyl ether mixture. Yield: $117.1 \mathrm{mg}(61 \%)$. IR (KBr): $\nu 2095.28 \mathrm{~cm}^{-1}$ (C三C). ${ }^{1} \mathrm{H}$ NMR $\left(400 \mathrm{MHz}, \mathrm{CDCl}_{3}\right): \delta 8.98\left(\mathrm{~s}, 4 \mathrm{H}, \mathrm{CH}_{\mathrm{pyr}}\right), 8.70\left(\mathrm{~d},{ }^{3} J_{\mathrm{H}-\mathrm{H}}=\right.$ $\left.1.2 \mathrm{~Hz}, 8 \mathrm{H}, \mathrm{CH}_{\text {pyr-im }}\right), 8.53\left(\mathrm{~s}, 2 \mathrm{H}, \mathrm{CH}_{\mathrm{pyr}}\right), 8.25\left(\mathrm{~d},{ }^{3} J_{\mathrm{H}-\mathrm{H}}=1.4 \mathrm{~Hz}\right.$, $\left.8 \mathrm{H}, \mathrm{CH}_{\text {pyr-im }}\right), 8.09\left(\mathrm{~s}, 8 \mathrm{H}, \mathrm{CH}_{\text {pyr-im }}\right), 5.35\left(\mathrm{t},{ }^{3} J_{\mathrm{H}-\mathrm{H}}=15.1 \mathrm{~Hz}, 16 \mathrm{H}\right.$, $\mathrm{NCH}_{2} \mathrm{CH}_{2} \mathrm{CH}_{2} \mathrm{CH}_{3}$ ), 2.24 (q, $16 \mathrm{H}, \mathrm{NCH}_{2} \mathrm{CH}_{2} \mathrm{CH}_{2} \mathrm{CH}_{3}$ ), $1.82-1.76$ $\left(\mathrm{m}, 16 \mathrm{H}, \mathrm{NCH}_{2} \mathrm{CH}_{2} \mathrm{CH}_{2} \mathrm{CH}_{3}\right), 1.63\left(\mathrm{~s}, 72 \mathrm{H}, \mathrm{C}\left(\mathrm{CH}_{3}\right)_{3}\right), 1.11\left(\mathrm{t},{ }^{3} J_{\mathrm{H}-\mathrm{H}}\right.$ $\left.=14.7 \mathrm{~Hz}, 24 \mathrm{H}, \mathrm{NCH}_{2} \mathrm{CH}_{2} \mathrm{CH}_{2} \mathrm{CH}_{3}\right) \cdot{ }^{13} \mathrm{C}\left\{{ }^{1} \mathrm{H}\right\}$ NMR (100 MHz, $\left.\mathrm{CDCl}_{3}\right): \delta 193.52$ (Au- $\left.C_{\text {carbene }}\right), 149.22\left(C_{\mathrm{q} \text { pyr-im }}\right), 134.70\left(\mathrm{CH}_{\mathrm{pyr}}\right)$, $133.07\left(C_{\mathrm{q}, \text { pyr }}\right), 131.95\left(C_{\mathrm{q}, \text { pyr-im }}\right), 128.45\left(C_{\mathrm{q}, \text { pyr-im }}\right), 128.04\left(\mathrm{CH}_{\text {pyr-im }}\right)$, $126.87\left(\mathrm{CH}_{\mathrm{pyr}}\right), 122.96\left(\mathrm{C}_{\mathrm{q}, \text { acetylide }}\right), 122.89\left(\mathrm{CH}_{\mathrm{pyr}-\mathrm{im}}\right), 121.71$ $\left(C_{\mathrm{q}, \mathrm{pyr}-\mathrm{im}}\right), 120.98\left(C_{\mathrm{q}, \mathrm{pyr}-\mathrm{im}}\right), 120.94\left(C_{\mathrm{q}, \mathrm{pyr}}\right), 120.43\left(C_{\mathrm{q}, \mathrm{pyr}}\right), 116.86$ $\left(\mathrm{CH}_{\text {pyr-im }}\right), 104.61$ ( $\left.\mathrm{C}_{\text {q,acetylide }}\right), 52.36\left(\mathrm{NCH}_{2} \mathrm{CH}_{2} \mathrm{CH}_{2} \mathrm{CH}_{3}\right), 35.62$ $\left(\mathrm{C}\left(\mathrm{CH}_{3}\right)\right), 32.83\left(\mathrm{NCH}_{2} \mathrm{CH}_{2} \mathrm{CH}_{2} \mathrm{CH}_{3}\right), 32.01\left(\mathrm{C}\left(\mathrm{CH}_{3}\right)\right), 20.42$ $\left(\mathrm{NCH}_{2} \mathrm{CH}_{2} \mathrm{CH}_{2} \mathrm{CH}_{3}\right), 14.24\left(\mathrm{NCH}_{2} \mathrm{CH}_{2} \mathrm{CH}_{2} \mathrm{CH}_{3}\right)$. Anal. Calcd for $\mathrm{C}_{156} \mathrm{H}_{174} \mathrm{~N}_{8} \mathrm{Au}_{4}$ : C, 63.54; H, 5.95; N, 3.80. Found: C, 64.80; H, 5.88; $\mathrm{N}, 3.84$.

Synthesis of 5. $\left[\mathrm{AuCl}\left(\mathrm{PPh}_{3}\right)\right](150 \mathrm{mg}, 0.303 \mathrm{mmol})$ was added to a suspension of compound $\mathbf{A}(22.6 \mathrm{mg}, 0.076 \mathrm{mmol})$ and $\mathrm{NaOH}(21.3$ $\mathrm{mg}, 0.532 \mathrm{mmol})$ in $\mathrm{MeOH}(30 \mathrm{~mL})$. After the general workup, complex 5 was isolated as a red solid upon precipitation from a dichloromethane/hexane mixture. The resulting solid was washed with $\mathrm{MeOH}$ and collected by filtration. Complex 5 was isolated as a bright red solid. Yield: $51.0 \mathrm{mg}(30 \%)$. IR (KBr): $\nu 2095.28 \mathrm{~cm}^{-1}$ (C三C). ${ }^{1} \mathrm{H}$ NMR $\left(400 \mathrm{MHz}, \mathrm{CDCl}_{3}\right): \delta 8.83\left(\mathrm{~s}, 4 \mathrm{H}, \mathrm{CH}_{\mathrm{pyr}}\right), 8.36(\mathrm{~s}, 2 \mathrm{H}$, $\left.\mathrm{CH}_{\text {pyr }}\right)$, 7.65-7.48 (m, 60H, $\left.\mathrm{CH}_{\text {phenyl }}\right) .{ }^{31} \mathrm{P}\left\{{ }^{1} \mathrm{H}\right\}$ NMR $(162 \mathrm{MHz}$, $\left.\mathrm{CDCl}_{3}\right): \delta 42.30(\mathrm{P}-\mathrm{Au})$. Anal. Calcd for $\mathrm{C}_{96} \mathrm{H}_{66} \mathrm{P}_{4} \mathrm{Au}_{4} \cdot 3 \mathrm{CH}_{2} \mathrm{Cl}_{2}: \mathrm{C}$, 49.83; H, 3.04. Found: C, 49.77; H, 3.00.

\section{ASSOCIATED CONTENT}

\section{S Supporting Information}

The Supporting Information is available free of charge on the ACS Publications website at DOI: 10.1021/acs.organomet.8b00217.

NMR spectra of complexes 3-5, X-ray crystallographic data of complex 3, UV-vis, excitation, and emission spectra of $\mathbf{A}$ and 3-5, emission spectra of 3-5 in the solid state, images of confocal microscopy, and molecular aggregation studies (PDF)

\section{Accession Codes}

CCDC 1824571 contains the supplementary crystallographic data for this paper. These data can be obtained free of charge via www.ccdc.cam.ac.uk/data_request/cif, or by emailing data request@ccdc.cam.ac.uk, or by contacting The Cambridge Crystallographic Data Centre, 12 Union Road, Cambridge CB2 1EZ, UK; fax: +44 1223336033.

\section{AUTHOR INFORMATION}

\section{Corresponding Author}

*E-mail for M.P.: poyatosd@uji.es.

\section{ORCID $\odot$}

Vanesa Fernández-Moreira: 0000-0002-1218-7218

M. Concepción Gimeno: 0000-0003-0553-0695

Eduardo Peris: 0000-0001-9022-2392

Macarena Poyatos: 0000-0003-2000-5231

\section{Notes}

The authors declare no competing financial interest.

\section{ACKNOWLEDGMENTS}

We gratefully acknowledge financial support from the MINECO of Spain (CTQ2014-51999-P and CTQ201675816-C2-1-P) and the Universitat Jaume I (UJI-B2017-07 and P11B2015-24). We are grateful to the Serveis Centrals d'Instrumentació Científica (SCIC-UJI) for providing with spectroscopic facilities. We also thank Dr. Louise N. Dawe (Wilfrid Laurier University) for her valuable advice on the refinement of the X-ray crystal structure of complex 3 .

\section{REFERENCES}

(1) (a) Kido, J.; Kimura, M.; Nagai, K. Science 1995, 267, 13321334. (b) Burroughes, J. H.; Bradley, D. D. C.; Brown, A. R.; Marks, R. N.; Mackay, K.; Friend, R. H.; Burn, P. L.; Holmes, A. B. Nature 1990, 347, 539-541.

(2) (a) Chen, X. Q.; Tian, X. Z.; Shin, I.; Yoon, J. Chem. Soc. Rev. 2011, 40, 4783-4804. (b) Chen, X. Q.; Wang, F.; Hyun, J. Y.; Wei, T. W.; Qiang, J.; Ren, X. T.; Shin, I.; Yoon, J. Chem. Soc. Rev. 2016, 45, 2976-3016. (c) Niu, L. Y.; Chen, Y. Z.; Zheng, H. R.; Wu, L. Z.; Tung, C. H.; Yang, Q. Z. Chem. Soc. Rev. 2015, 44, 6143-6160. (d) Vendrell, M.; Zhai, D. T.; Er, J. C.; Chang, Y. T. Chem. Rev. 2012, 112, 4391-4420. (e) Yang, S. K.; Shi, X. H.; Park, S.; Ha, T.; Zimmerman, S. C. Nat. Chem. 2013, 5, 692-697. (f) Wu, J. S.; Liu, W. 
M.; Ge, J. C.; Zhang, H. Y.; Wang, P. F. Chem. Soc. Rev. 2011, 40, 3483-3495.

(3) (a) Dai, X. L.; Zhang, Z. X.; Jin, Y. Z.; Niu, Y.; Cao, H. J.; Liang, X. Y.; Chen, L. W.; Wang, J. P.; Peng, X. G. Nature 2014, 515, 96-99.

(b) Zhu, M. R.; Yang, C. L. Chem. Soc. Rev. 2013, 42, 4963-4976.

(4) (a) Ashton, T. D.; Jolliffe, K. A.; Pfeffer, F. M. Chem. Soc. Rev. 2015, 44, 4547-4595. (b) Yao, J.; Yang, M.; Duan, Y. X. Chem. Rev. 2014, 114, 6130-6178.

(5) (a) Hong, Y. N.; Lam, J. W. Y.; Tang, B. Z. Chem. Commun. 2009, 4332-4353. (b) Hong, Y. N.; Lam, J. W. Y.; Tang, B. Z. Chem. Soc. Rev. 2011, 40, 5361-5388. (c) Mei, J.; Leung, N. L. C.; Kwok, R. T. K.; Lam, J. W. Y.; Tang, B. Z. Chem. Rev. 2015, 115, 11718-11940. (d) Hu, R.; Leung, N. L. C.; Tang, B. Z. Chem. Soc. Rev. 2014, 43, 4494-4562.

(6) Fernández-Moreira, V.; Gimeno, M. C. Chem. - Eur. J. 2018, 24, 3345-3353.

(7) (a) Wagenknecht, P. S.; Ford, P. C. Coord. Chem. Rev. 2011, 255, 591-616. (b) Chou, P. T.; Chi, Y.; Chung, M. W.; Lin, C. C. Coord. Chem. Rev. 2011, 255, 2653-2665. (c) Heine, J.; Müller-Buschbaum, K. Chem. Soc. Rev. 2013, 42, 9232-9242.

(8) Lima, J. C.; Rodriguez, L. Chem. Soc. Rev. 2011, 40, 5442-5456.

(9) Visbal, R.; Gimeno, M. C. Chem. Soc. Rev. 2014, 43, 3551-3574.

(10) (a) Visbal, R.; Ospino, I.; Lopez-de-Luzuriaga, J. M.; Laguna, A.; Gimeno, M. C. J. Am. Chem. Soc. 2013, 135, 4712-4715. (b) To, W. P.; Chan, K. T.; Tong, G. S. M.; Ma, C. S.; Kwok, W. M.; Guan, X. G.; Low, K. H.; Che, C. M. Angew. Chem., Int. Ed. 2013, 52, 6648-6652.

(c) To, W. P.; Zhou, D. L.; Tong, G. S. M.; Cheng, G.; Yang, C.; Che, C. M. Angew. Chem., Int. Ed. 2017, 56, 14036-14041. (d) Wong, B. Y. W.; Wong, H. L.; Wong, Y. C.; Au, V. K. M.; Chan, M. Y.; Yam, V. W. W. Chem. Sci. 2017, 8, 6936-6946.

(11) Chan, K. T.; Tong, G. S. M.; To, W. P.; Yang, C.; Du, L. L.; Phillips, D. L.; Che, C. M. Chem. Sci. 2017, 8, 2352-2364.

(12) Sinha, N.; Stegemann, L.; Tan, T. T. Y.; Doltsinis, N. L.; Strassert, C. A.; Hahn, F. E. Angew. Chem., Int. Ed. 2017, 56, 27852789.

(13) (a) Figueira-Duarte, T. M.; Muellen, K. Chem. Rev. 2011, 111, 7260-7314. (b) Winnik, F. M. Chem. Rev. 1993, 93, 587-614.

(14) Jahnke, M. C.; Paley, J.; Hupka, F.; Weigand, J. J.; Hahn, F. E. Z. Naturforsch., B: J. Chem. Sci. 2009, 64, 1458-1462.

(15) Ibañez, S.; Poyatos, M.; Peris, E. Organometallics 2017, 36, 1447-1451.

(16) Schmidbaur, H.; Schier, A. Chem. Soc. Rev. 2008, 37, 19311951.

(17) Shyamala, T.; Sankararaman, S.; Mishra, A. K. Chem. Phys. 2006, 330, 469-477.

(18) Valdes, H.; Poyatos, M.; Peris, E. Inorg. Chem. 2015, 54, 36543659 .

(19) Karpovich, D. S.; Blanchard, G. J. J. Phys. Chem. 1995, 99, 3951-3958.

(20) Liu, W.; Gust, R. Coord. Chem. Rev. 2016, 329, 191-213.

(21) Li, Q.; Li, J. Y.; Ren, H. C.; Gao, Z. X.; Liu, D. Synth. Commun. 2011, 41, 3325-3333.

(22) (a) Venkataramana, G.; Sankararaman, S. Eur. J. Org. Chem. 2005, 2005, 4162-4166. (b) Bernhardt, S.; Kastler, M.; Enkelmann, V.; Baumgarten, M.; Mullen, K. Chem. - Eur. J. 2006, 12, 6117-6128.

(23) Nuevo, D.; Gonell, S.; Poyatos, M.; Peris, E. Chem. - Eur. J. 2017, 23, 7272-7277.

(24) Bruce, M. I.; Nicholson, B. K.; Binshawkataly, O.; Shapley, J. R.; Henly, T. Inorg. Synth. 2007, 26, 324-328. 